\title{
Transformed tissue of Dionaea muscipula J. Ellis as a source of biologically active phenolic compounds with bactericidal properties
}

\author{
Wojciech Makowski ${ }^{1}$ (D) Aleksandra Królicka ${ }^{2} \cdot$ Anna Nowicka $^{3,4} \cdot$ Jana Zwyrtková $^{3} \cdot$ Barbara Tokarz $^{1} \cdot$ Ales Pecinka $^{3}$. \\ Rafał Banasiuk $^{5} \cdot$ Krzysztof Michał Tokarz ${ }^{1}$
}

Received: 14 August 2020 / Revised: 2 December 2020 / Accepted: 5 January 2021 / Published online: 15 January 2021

(C) The Author(s) 2021

\begin{abstract}
The Venus flytrap (Dionaea muscipula J. Ellis) is a carnivorous plant able to synthesize large amounts of phenolic compounds, such as phenylpropanoids, flavonoids, phenolic acids, and 1,4-naphtoquinones. In this study, the first genetic transformation of D. muscipula tissues is presented. Two wild-type Rhizobium rhizogenes strains (LBA 9402 and ATCC 15834) were suitable vector organisms in the transformation process. Transformation led to the formation of teratoma (transformed shoot) cultures with the bacterial rolB gene incorporated into the plant genome in a single copy. Using high-pressure liquid chromatography, we demonstrated that transgenic plants were characterized by an increased quantity of phenolic compounds, including 1,4naphtoquinone derivative, plumbagin (up to $106.63 \mathrm{mg} \times \mathrm{g}^{-1} \mathrm{DW}$ ), and phenolic acids (including salicylic, caffeic, and ellagic acid), in comparison to non-transformed plants. Moreover, Rhizobium-mediated transformation highly increased the bactericidal properties of teratoma-derived extracts. The antibacterial properties of transformed plants were increased up to $33 \%$ against Staphylococcus aureus, Enterococcus faecalis, and Escherichia coli and up to $7 \%$ against Pseudomonas aeruginosa. For the first time, we prove the possibility of $D$. muscipula transformation. Moreover, we propose that transformation may be a valuable tool for enhancing secondary metabolite production in D. muscipula tissue and to increase bactericidal properties against human antibiotic-resistant bacteria.
\end{abstract}

\section{Key points}

- Rhizobium-mediated transformation created Dionaea muscipula teratomas.

- Transformed plants had highly increased synthesis of phenolic compounds.

- The MBC value was connected with plumbagin and phenolic acid concentrations.

Keywords Phenolic acids $\cdot$ Plumbagin $\cdot$ Rhizobium rhizogenes $\cdot$ Teratomas $\cdot$ Venus flytrap

Wojciech Makowski

wojtek.makowski.1305@gmail.com

Aleksandra Królicka

aleksandra.krolicka@biotech.ug.edu.pl

1 Department of Botany, Physiology and Plant Protection, Faculty of Biotechnology and Horticulture, University of Agriculture in Krakow, Krakow, Poland
2 Intercollegiate Faculty of Biotechnology UG and MUG, Laboratory of Biologically Active Compounds, University of Gdansk, Gdansk, Poland

3 Institute of Experimental Botany, Czech Acad Sci, Centre of the Region Haná for Biotechnological and Agricultural Research, Olomouc, Czech Republic

4 The Franciszek Górski Institute of Plant Physiology, The Polish Academy of Sciences, Krakow, Poland

5 Institute of Biotechnology and Molecular Medicine, Gdansk, Poland 


\section{Introduction}

Rhizobium rhizogenes (former: Agrobacterium rhizogenes) is bacteria from the family Rhizobiaceae and is a "natural genetic engineer" because of the ability to transfer T-DNA (transfer DNA) and incorporate bacteria-derived genes into the plant genome (Georgiev et al. 2007). The natural features of this Gram-negative soil bacterium are used in the plant biotechnology for obtaining transformed organisms with new unique properties. During T-DNA transfer to plant cells, $R$. rhizogenes pass on the set of rol genes occurring in $\mathrm{Ri}$ plasmids (root-inducing plasmids). These genes encode specific proteins responsible for control over auxin and cytokinin synthesis in plant cells (Guillon et al. 2006). Usually, the consequence of $R$. rhizogenes infection is the change in plant hormone balance and rise of the hairy root phenotype. However, depending on the plant genotype, transformed shoots (teratomas) may occur instead of hairy roots (Królicka et al. 2010). Despite the infection mechanism of plants by $R$. rhizogenes being known for a few decades, the physiological consequences of such events related to plant species need to be studied.

Because of the increasing demand for plant-derived phytochemicals and the consumption of herbal medicines (Canter et al. 2005), genetic transformation found application in the field of medicinal plants (Niazian 2019). Hairy roots or teratomas of medicinal plants characterized by a fast growth rate and biochemical stability are promising sources of plant secondary metabolites in large-scale propagation (Georgiev et al. 2007). Moreover, they can serve as a scientific model for studies on secondary metabolism engineering and the overproduction of phytochemicals of interests in plant tissue culture (Tusevski et al. 2017). To the best of our knowledge, many Rhizobium-mediated transformations were successfully established in medicinal plants (Królicka et al. 2001; Gangopadhyay et al. 2010; Libik-Konieczny et al. 2020), while transformation protocol for carnivorous plant Dionaea muscipula J. Ellis (Venus flytrap) is still missing.

Carnivorous plants belonging to the family Droseraceae have been used in natural medicine for centuries (Królicka et al. 2010). The healing properties of these plants arise from the ability to produce large amounts of phenolic compounds with strong biological activity (Gaascht et al. 2013). Extracts from carnivorous plant tissues were proven to have antibacterial (Krolicka et al. 2008; Makowski et al. 2020), antioxidative (Królicka et al. 2009; Makowski et al. 2020), antifungal (Padhye et al. 2010), and anticancer properties (Kawiak et al. 2019). Moreover, previous phytochemical studies showed that the species most abundant in phenolic derivatives in the family Droseraceae is D. muscipula (Gaascht et al. 2013). The major 1,4-naphtoquinone derivative in the biochemical composition of the Venus flytrap is plumbagin. Furthermore, concentrations of this metabolite in D. muscipula tissue are higher than in other commonly used sources of plumbagin, like Plumbago plants (Makowski et al. 2020).

Since plants from the family Droseraceae are endangered species and exploitation of natural habitats is impossible, in vitro propagation protocols were established (Banasiuk et al. 2012). Therefore, the implementation of biotechnological tools for the enhancement of secondary metabolite production, like elicitation (Putalun et al. 2010; Boonsnongcheepa et al. 2019) or genetic transformation became possible (Królicka et al. 2010). Nevertheless, increasing valuable phytochemicals with elicitation and obtaining transformed plants is a difficult task because of carnivorous plant biology (Blehova et al. 2015; Makowski et al. 2019).

The main goals of the presented study were (i) transformation of the medicinal plant $D$. muscipula using wild strains of $R$. rhizogenes bacteria, (ii) with simultaneously increased synthesis of phenolic compounds, in particular plumbagin, and (iii) evaluation of bactericidal properties of extracts derived from transformed plants against clinical strains of pathogenic bacteria. We hypothesized that inoculation of the Venus flytrap with Rhizobium bacteria would incorporate rol genes into plant DNA. The purpose was to establish transformed clones characterized by fast growth and high productivity of valuable secondary metabolites with strong biological activity.

\section{Materials and methods}

\section{Plant materials and bacterial strains used for transformation}

D. muscipula plants were propagated in in vitro conditions, according to Makowski et al. (2019). Whole plant tissue cultures were cultivated on $1 / 2$ MS medium (Murashige and Skoog 1962) with no growth regulators, 3\% sucrose, and pH 5.5 (adjusted before autoclaving), solidified with $0.75 \%$ of agar. Conditions included a temperature of $23 \pm 1{ }^{\circ} \mathrm{C}$, fluorescence light of $80 \mu \mathrm{mol} \times \mathrm{m}^{-2} \times \mathrm{s}^{-1}$ photosynthetic photon flux density (PPFD), and a photoperiod of $16 \mathrm{~h} / 8 \mathrm{~h}$ light/dark cycle. Plants were subcultured in 30-day intervals.

Wild $R$. rhizogenes strains, including LBA 9402 (NCPPB 1855), ATCC 15834, and A4 (ATCC 31798) were obtained from the Laboratory of Biologically Active Compounds, University of Gdansk, Poland. Bacteria were grown on yeast extract beef (YEB) agar medium with $200 \mu \mathrm{M}$ of acetosyringone (Sigma) at $26{ }^{\circ} \mathrm{C}$ in the dark. For plant transformation, 48-h bacterial cultures were used.

\section{Transformation of $D$. muscipula plants}

Young (4-week-old) Venus flytrap rhizomes (150 pieces) were inoculated for each $R$. rhizogenes bacteria strain. 
Inoculation was performed with preparation needle, according to Królicka et al. (2010). After inoculation, rhizomes were subcultured to $1 / 2 \mathrm{MS}$ medium supplemented with $3 \%$ sucrose and $0.8 \%$ of agar with $\mathrm{pH} 5.5$ and grown for 3 days in the dark. Next, co-cultures were transferred to $1 / 2 \mathrm{MS}$ medium supplemented with antibiotics, claforan and carbenicillin (500 $\mathrm{mg} \times \mathrm{L}^{-1}$ each), to eliminate $R$. rhizogenes. After 4 weeks of cultivation in the dark, new transformed shoots of D. muscipula were excised and placed on fresh MS medium with the same antibiotic concentrations listed above and grown in the dark for 8 weeks. After 7 subcultures, axenic cultures were established from a single shoot of transgenic tissue. Next, transformed clones were subcultured on fresh MS media without antibiotic growth regulators. Transformed clones of D. muscipula were propagated for 8 weeks in liquid media, as described by Makowski et al. (2020). During this time, observations of plant morphology, growth rate, and preliminary screening for phenolic compound quantity in comparison to non-transformed plants were performed. Based on these observations, four transformed clones of D. muscipula were chosen for further analysis.

Transformed cultures were also tested for the presence of live $R$. rhizogenes found in tissue. Transformed shoots were homogenized and the obtained suspensions were plated on YEB agar medium and grown for 5 days at $26^{\circ} \mathrm{C}$ in the dark.

\section{Molecular analysis}

To confirm transformation on a molecular level, a PCR reaction for the detection of bacteria T-DNA fragments in the plant genome was performed. To estimate the number of bacterial genes copies in plant genome Southern hybridization was used. Total genomic DNA from transformed and nontransformed D. muscipula plants was isolated using the CTAB method by Bekesiova et al. (1999). This method yields high-quality DNA, free from secondary metabolites. As a positive control in PCR, plasmid DNA from bacteria cells was used. A culture of 24 -h old $R$. rhizogenes $\left(\mathrm{OD}_{600} 4.0\right)$ was extracted using alkaline lysis as described by Maniatis et al. (1982). Oligonucleotide primers for the PCR detection of rolB (forward primer 5'-GCTCTTGCAGTGCTAGATTT-3', reverse primer 5'-GAAGGTGCAAGCTACCTCTC-3'), rolC (forward primer 5'-CTCCTGACATCAAACTCGTC-3', reverse primer $5^{\prime}$-TGCTTCGAGTTATGGGTACA-3'), and vir G (forward primer 5'-ACTGAATATCAGGCAACGCC3', reverse primer 5'-GCGTCAAAGAAATAGCCAGC-3') were used (Królicka et al. 2010). PCR was performed in three biological replicates for each examined transformed clone and non-transformed plant.

Southern hybridization was performed to evaluate the number of rolB and rolC gene copies incorporated in the plant genome. The probes for hybridization specific for rolB and rolC genes were prepared from Ri Plasmid and directly labeled using PCR with biotin-dUTP. Plant genomic DNA was isolated as described in the previous section. Two micrograms DNA was digested overnight at $37^{\circ} \mathrm{C}$ with 1 unit of BamHI enzyme (Thermo Fisher Scientific, Waltham, MA, USA). Subsequently, the samples were electrophoretically separated overnight on 1.2\% 2-amino-2-(hydroxymethyl)1,3-propanediol (TRIS)-borate-EDTA agarose gels, depurinated, denatured, and neutralized as described (Nowicka et al. 2020). Blotting was performed for $7 \mathrm{~h}$ on Hybond $^{\mathrm{TM}} \mathrm{N}+$ nylon membrane (GE Healthcare, Chicago, IL, USA) with $20 \times$ SSC, washed in $2 \times$ SSC, dried, and crosslinked using UV Stratalinker (Agilent, Santa Clara, CA, USA). Pre-hybridization, overnight hybridization, and posthybridization washes were performed as described in (Nowicka et al. 2020).

Hybridization points were detected using the Chemiluminescent Nucleic Acid Detection Module Kit (Thermo Fisher Scientific, Waltham, MA, USA). To visualize, resulted signals were used Medical X-Ray Film Blue (Agfa Healthcare, Mortsel, Belgium).

\section{Determination of biometric parameters}

To estimate the growth of examined plants, transformed clones and non-transformed plants were harvested and weighed immediately. A growth index (GI) was calculated according to the formula: GI [\%] $=\left(\mathrm{FW}_{2}-\mathrm{FW}_{1}\right) / \mathrm{FW}_{2} \times$ 100 , where $\mathrm{FW}_{1}$ was the fresh weight of plants at the beginning of the experiment and $\mathrm{FW}_{2}$ was a final fresh weight. To determine dry weight (DW) accumulation, plants were freezedried for $72 \mathrm{~h}$ and weighed. DW content in plant tissue was calculated according to the formula: DW $[\%]=\mathrm{DW}_{2} \times 100 /$ $\mathrm{FW}_{2}$, where $\mathrm{DW}_{2}$ was dry weight after freeze-drying. Freezedried plant tissue was homogenized and stored at $-20^{\circ} \mathrm{C}$ for further analysis.

\section{Biochemical analysis}

Spectrophotometric and HPLC analysis were performed to estimate level of phenolic compounds in transformed and non-transformed plants. Total phenolic content was estimated according to the method by Swain and Hillis (1959) with Folin-Ciocalteu's reagent, after modifications (Tokarz et al. 2018). Freeze-dried tissue $(10 \mathrm{mg}$ ) was extracted in $80 \%$ $\mathrm{MeOH}$ at $4{ }^{\circ} \mathrm{C}$. Samples were centrifuged for $15 \mathrm{~min}$ $\left(25,155 \mathrm{~g}, 4^{\circ} \mathrm{C}\right)$. One milliliter of diluted extract was mixed with $0.2 \mathrm{~mL}$ Folin's reagent (Sigma-Aldrich Chemie, GmBH, Steinheim, Germany) and $1.6 \mathrm{~mL} 5 \% \mathrm{Na}_{2} \mathrm{CO}_{3}$ and incubated for $20 \mathrm{~min}$ at $40{ }^{\circ} \mathrm{C}$. The absorbance of the mixture was measured at $740 \mathrm{~nm}$ using a Double Beam spectrophotometer U-2900 (Hitachi High-Technologies Corporation, Japan). Chlorogenic acid (Sigma-Aldrich Chemie, GmBH, Steinheim, Germany) was used as a reference standard. 
Results were expressed as milligram of chlorogenic acid equivalents per $1 \mathrm{~g}$ of DW. Analyses were performed in five biological replicates.

To determine the accumulation of phenylpropanoids, flavonoids, and anthocyanins in plant tissue, a method described by Fukumoto and Mazza (2000) was used with modifications (Tokarz et al. 2020). Tissue was extracted as described in the method for total phenolic content estimation. The supernatant $(0.25 \mathrm{~mL})$ was mixed with $0.25 \mathrm{~mL} 0.1 \%$ $\mathrm{HCl}$ in $96 \% \mathrm{EtOH}$ and $4.55 \mathrm{~mL} 2 \% \mathrm{HCl}$ in $\mathrm{H}_{2} \mathrm{O}$. Test tubes with mixtures were incubated for $20 \mathrm{~min}$ in the dark. The absorbance of samples was measured at wavelengths of 320 , 360 , and $520 \mathrm{~nm}$. Contents of phenylpropanoids, flavonoids, and anthocyanins were calculated using calibration curves made for caffeic acid, quercetin, and cyanidin (SigmaAldrich Chemie, GmBH, Steinheim, Germany), respectively. The results were expressed as milligrams of standard equivalents per $1 \mathrm{~g}$ of DW. Analyses were performed in five replicates.

To estimate plumbagin content, $10 \mathrm{mg}$ of freeze-dried plant tissue was extracted in $0.6 \mathrm{~mL}$ of MQ water and $0.6 \mathrm{~mL}$ of tetrahydrofuran (THF) (Tokarz et al. 2018). For analysis of caffeic acid, hyperoside, ellagic acid, salicylic acid, myricetin, and quercetin dry tissue $(20 \mathrm{mg})$ was extracted in $2 \mathrm{~mL}$ of $100 \%$ methanol and sonicated for $30 \mathrm{~min}$ (Makowski et al. 2020). Samples were centrifuged $\left(15 \mathrm{~min}, 25,155 \mathrm{~g}, 4^{\circ} \mathrm{C}\right)$ and filtered. Chromatographic separation was performed according to Makowski et al. (2020) using Dionex UltiMate 3000 HPLC system equipped with a quaternary pump, autosampler, column oven, and UV detector. For the stationary phase, Agilent Zorbax SB-Phenyl $(4.6 \times 150 \mathrm{~mm}, 3.5 \mu \mathrm{m})$ was used. The flow rate was $1 \mathrm{~mL} \times \mathrm{min}^{-1}$. The sample injection volume was $10 \mu \mathrm{L}$. The mobile phase for the analysis consisted of $0.1 \%(\mathrm{v} / \mathrm{v})$ trifluoroacetic acid in acetonitrile as eluent $\mathrm{A}$ and $0.1 \%(\mathrm{v} / \mathrm{v})$ trifluoroacetic acid in water as eluent $\mathrm{B}$. The separation gradient was 0 min $(10 \% \mathrm{~A}) \rightarrow 5 \min (10 \% \mathrm{~A}) \rightarrow$ $12 \min (90 \% \mathrm{~A}) \rightarrow 20 \mathrm{~min}(90 \% \mathrm{~A})$, followed by $10-\mathrm{min}$ column regeneration. Chromatographic separations were carried out at $25^{\circ} \mathrm{C}$. Compounds present in examined plant tissues (plumbagin, hyperoxide, ellagic acid, myricetin, quercetin, salicylic acid, and caffeic acid) were used as standards to determine extract composition. A three-level standard curve was used for determining the concentration of the compounds 4-point. Monitoring was performed at $254 \mathrm{~nm}$. Each analysis was performed in three biological replicates.

\section{Productivity of phenolic derivatives}

The productivity $(P)$ of each phenolic compound was calculated according to the formula: $P$ [mg of phenolic compound/ 8 weeks/flask $]=A \times B$, where $A$ was the content of the phenolic compound in plant tissue after 8 weeks of growth and $B$ was the fold of weight gain of one tissue culture (one flask).
Antibacterial activity of plant-derived extracts

To evaluate the bactericidal properties of examined plants, minimal inhibition concentrations (MIC) and minimal bactericidal concentrations $(\mathrm{MBC})$ methods were used (Królicka et al. 2009). MIC and MBC were evaluated against antibiotic-resistant, human-pathogenic bacteria: Staphylococcus aureus ATCC 25923, Enterococcus faecalis ATCC 19433, Pseudomonas aeruginosa ATCC 27853, and Escherichia coli ATCC 25922, obtained from the IFB UG \& MUG Poland. The bacteria were cultivated on BHI medium (overnight, $37^{\circ} \mathrm{C}$ ). Freeze-dried plant tissue $(100 \mathrm{mg})$ was extracted in THF (Makowski et al. 2020). Extracts were evaporated and resuspended in methanol before application into wells of the 96-well plate. To remove toxic methanol, extracts were evaporated in the wells. The residues were suspended in $100 \mu \mathrm{L}$ of liquid BHI media, and bacterial suspensions $\left(10 \mu \mathrm{L}, 10^{5} \mathrm{CFU} \times\right.$ $\mathrm{mL}^{-1}$ ) in liquid media were added to wells. Plates were incubated overnight. The MIC value was defined as the lowest concentration of applied extract that inhibits bacteria growth in the well. To establish the MBC value, $100 \mu \mathrm{L}$ from each well that showed no visible growth of bacteria were plated out on a BHI agar plate for $24 \mathrm{~h}$ of incubation at $37^{\circ} \mathrm{C}$. The MBC was defined as the lowest concentration of the extract that reduced the inoculum by $99.9 \%$ within $24 \mathrm{~h}$.

\section{Statistical analyses}

One-way analysis of variance (ANOVA) was used to determine significant differences between means (Tukey test at $p<0.05$ level). STATISTICA 12.0 (StatSoft Inc., Tulsa, OK, USA) was used to carry out statistical analyses.

\section{Results}

\section{Obtaining transformed plants after inoculation with bacteria and molecular analysis}

D. muscipula tissue was inoculated with three different strains of wild-type $R$. rhizogenes: LBA 9402, ATCC 15834, and A4. Only inoculation with LBA 9402 and ATCC 15834 resulted in the appearance of presumably transformed shoots (teratomas). Hairy root production was not observed in teratomas tissue culture. Teratomas appearing efficiency was $14 \%$ and $16 \%$ for $R$. rhizogenes LBA 9402 and ATCC 15834, respectively. Based on preliminary results from growth observations and screening for phenolic compound accumulation in teratomas tissue compared to non-transformed plants (NT plants), four transformed clones of the Venus flytrap were taken for further analysis: clones $\mathrm{P}, \mathrm{K}, \mathrm{L}$, and $\mathrm{E}$. Clones $\mathrm{P}$ and $\mathrm{K}$ were obtained after inoculation with $R$. rhizogenes LBA 9402, while L and E with ATCC 15834. 
For molecular analysis of the incorporation of bacterial TDNA in the plant genome, PCR detection of rolB and rolC genes was performed. Presence of the rolB gene was confirmed for each putatively transformed $D$. muscipula clone ( $\mathrm{P}, \mathrm{K}, \mathrm{L}$, and $\mathrm{E}$ ), in each of three biological repetitions (samples from three independent tissue cultures), while the rolB gene was not detected in NT plants (Fig. 1). The presence of the rolC gene in transformed clones was not detected. For confirmation of $R$. rhizogenes elimination from tissue cultures of transformed plants, PCR for the vir G gene was performed. This gene was present in the Ri plasmid but beyond the transferred T-DNA and was not incorporated into the plant genome. $\operatorname{Vir} \mathrm{G}$ was not found in transformed tissue cultures.

To estimate the number of $r o l \mathrm{~B}$ and $r o l \mathrm{C}$ gene copies incorporated to the D. muscipula genome, Southern hybridization was performed. The obtained signals showed that each transformed clone of the Venus flytrap had a single copy of the searched rolB gene, visible as a single band in lanes 2, 3, 4, and 5 (Fig. 2), whereas the signals for rolC gene were not detected.

\section{Growth index, dry weight accumulation, and morphology of transformed clones}

After 8 weeks of cultivation of transformed clones and NT plants (control) in liquid media with rotary shaking, GI, DW content, and plant morphology were evaluated. Estimation of growth parameters showed that in comparison to NT plants, GI of clone K was significantly decreased by $29 \%$ (Fig. 3a) with simultaneously increased accumulation of DW by $15 \%$ (Fig. 3b). Clone L was characterized by 1.2-fold higher GI compared to NT plants (Fig. 3a) and changed morphology, including longer teratomas with bigger leave-traps (Fig. 3c).

\section{Total phenolic, phenylpropanoid, flavonoid, and anthocyanin content in transformed clones}

Next, we examined the synthesis of phenolic compounds in transformed clones of the Venus flytrap. Using

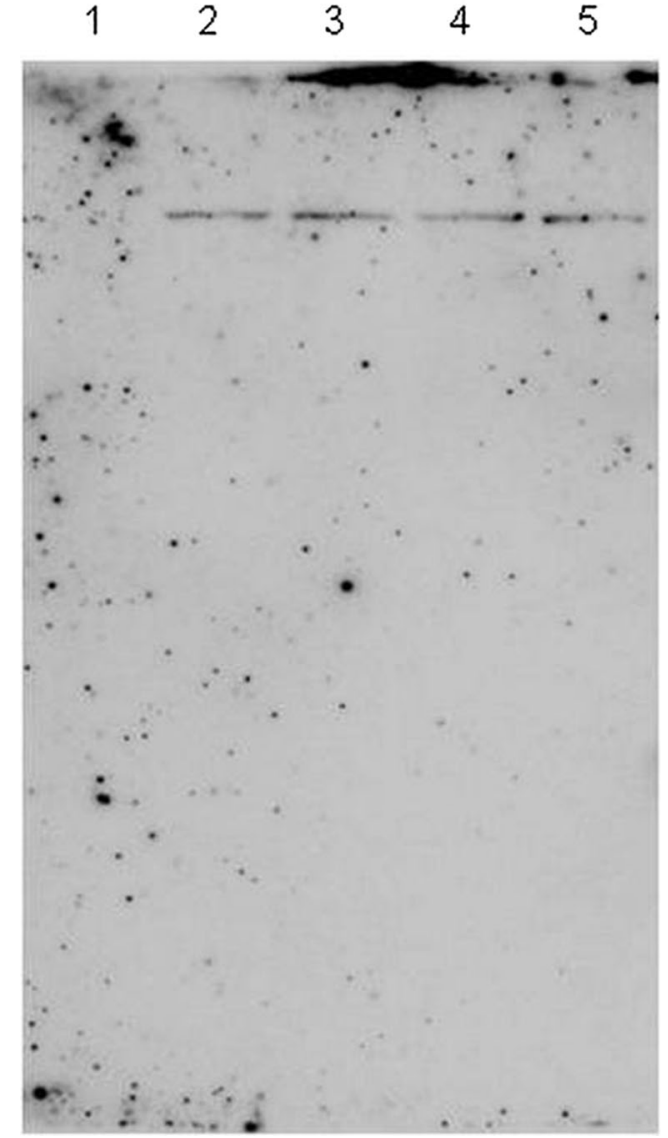

Fig. 2 Southern hybridization with the rolB probe: non-transformed tissue of Dionaea muscipula (lane 1) and transformed clones of Dionaea muscipula: clone P (lane 2), clone K (lane 3), clone L (lane 4), and clone $\mathrm{E}$ (lane 5). The number of bands in each lane show the number of rolB gene copies

spectrophotometric methods, total phenolic content and accumulation of selected groups of phenolic derivatives were evaluated. Transgenic D. muscipula plants had significantly increased accumulation of total phenolic content, phenylpropanoids, flavonoids, and anthocyanins in clone P, L, and E compared to NT plants (Fig. 4). Interestingly, clone K synthesized significantly less phenolic compounds

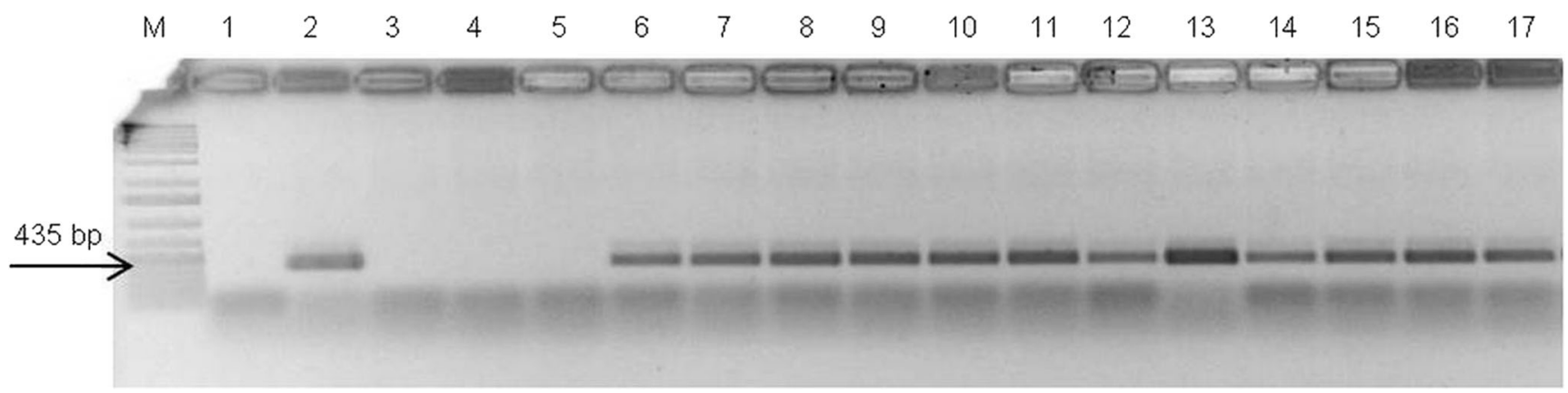

Fig. 1 PCR analysis of non-transformed tissue of Dionaea muscipula (lanes 3-5) and transformed clones of Dionaea muscipula: clone P (lanes 6-8), clone K (lanes 9-11), clone L (lanes 12-14), and clone E (lanes 15-17). Lane 1: negative control, lane 2: positive control
(Rhizobium rhizogenes ATCC 15834 plasmidic DNA). GeneRuler ${ }^{\mathrm{TM}}$ $100 \mathrm{bp}$ DNA ladder (lane M). Bands show amplified fragments of the rolB gene 
a

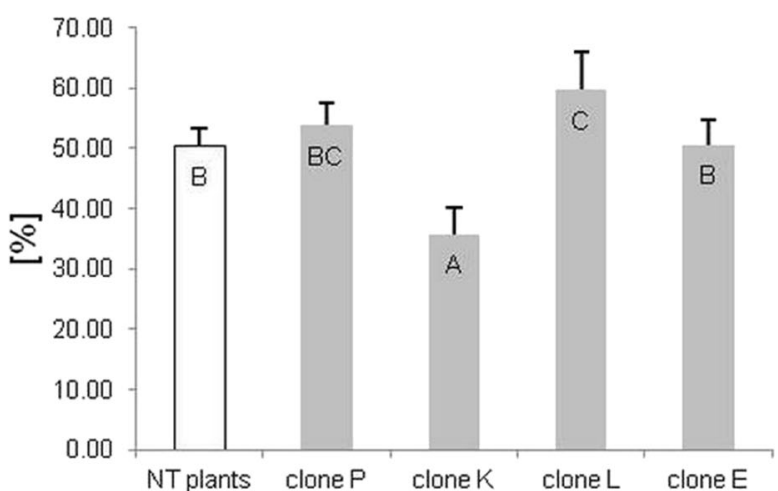

b

Dry weight

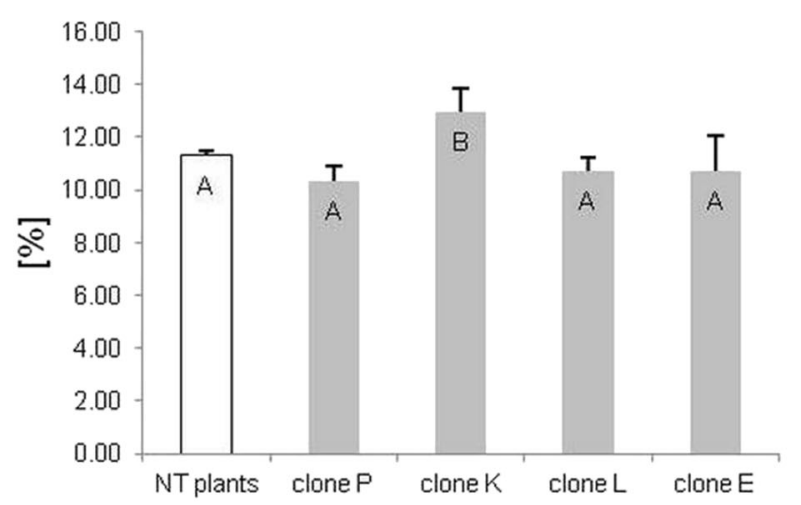

C

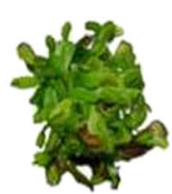

NT plants

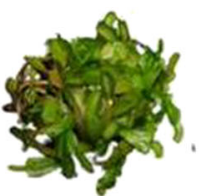

clone P

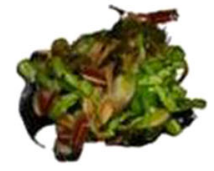

clone K
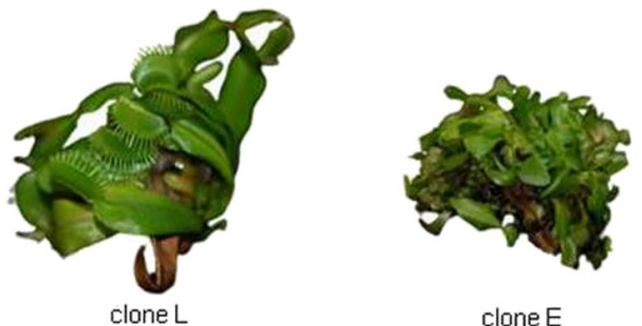

clone $\mathrm{E}$

$1 \mathrm{~cm}$

Fig. 3 a Growth index (\%), b dry weight (\%), and $\mathbf{c}$ morphology of non-transformed and transformed tissue of Dionaea muscipula clones

a

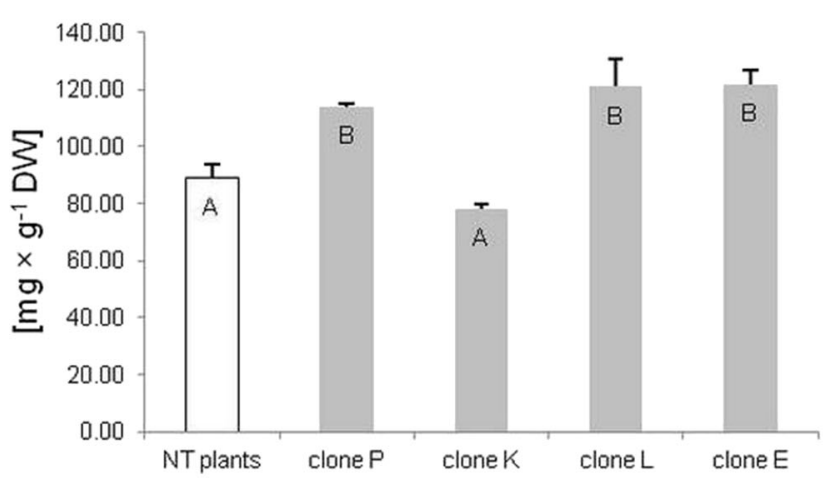

C

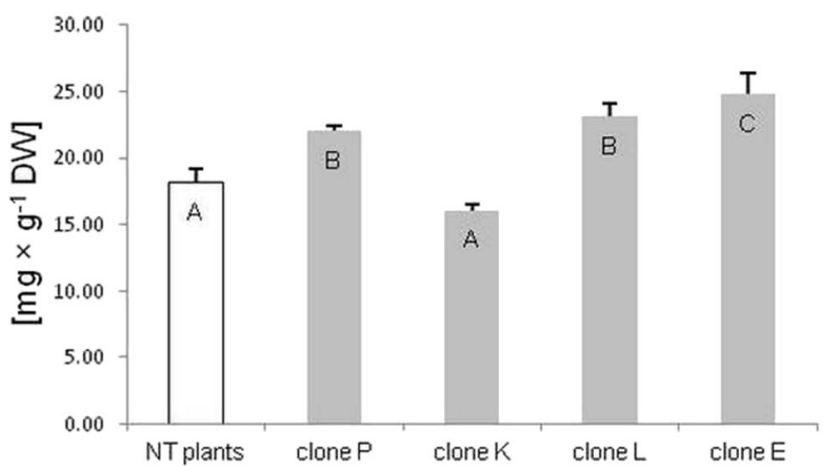

b

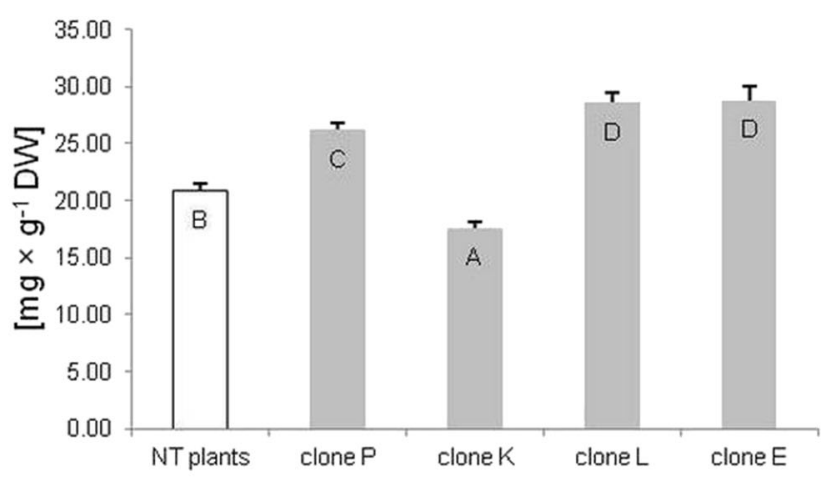

d

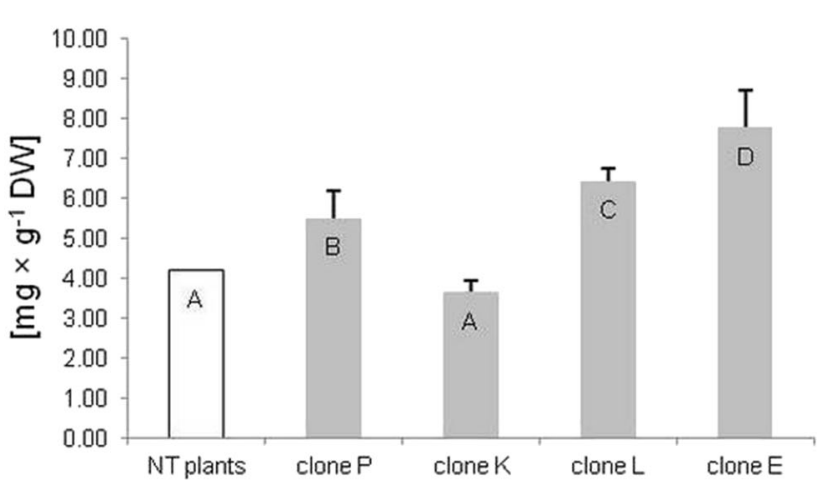

Fig. 4 Accumulation of phenolic compounds in non-transformed and transformed tissue of Dionaea muscipula clones: a total phenolic content, $\mathbf{b}$ phenylpropanoids, $\mathbf{c}$ flavonoids, and $\mathbf{d}$ anthocyanins. Different letters indicate significant differences between means at $p<0.05$; bar: standard deviation 
than control plants. Clone L was transformed with $R$. rhizogenes ATCC 15834 and accumulated significantly more phenylpropanoids and anthocyanins than those transformed with $R$. rhizogenes LBA 9402 (Fig. 4b and d).

\section{Accumulation and productivity of phenolic compound derivatives in transgenic clones}

To study how the transformation of D. muscipula with wild strains of $R$. rhizogenes bacteria affected the production of selected phenolic compounds, HPLC was used. In comparison to NT plants, phenolic compound metabolism in transformed clones was significantly affected (Table 1). Clones $\mathrm{P}, \mathrm{L}$, and $\mathrm{E}$ accumulated significantly increased amounts of plumbagin, salicylic acid, and ellagic acid, while among them, clone $\mathrm{E}$ reached the highest level of these metabolites (1.5-, 1.9-, and 1.8-fold higher than NT plants, respectively). The level of caffeic acid was increased in clones $\mathrm{L}$ and $\mathrm{E}$ by 68 and $42 \%$, respectively. Accumulation of hyperoside was significantly decreased in all transformed clones compared to NT plants (Table 1).

The productivity of phenolic compounds in obtained transgenic clones was calculated. Presented results showed that clone L was characterized by the best productivity of plumbagin, myricetin, caffeic acid, and ellagic acid, which increased 1.7-, 1.2-, 2.0-, and 2.0-fold, respectively. Clones $\mathrm{P}, \mathrm{L}$, and $\mathrm{E}$ had increased productivity of plumbagin, salicylic acid, and ellagic acid in comparison to NT plants, respectively. Decreased productivity of hyperoside was observed in all examined plants when compared to the control. Moreover, clone $\mathrm{K}$ was characterized by decreased productivity of myricetin, quercetin, and salicylic acid (Table 2).

\section{Bactericidal properties of extracts derived from transformed clones}

This study focused on the synthesis of phenolic compounds in the transformed tissue of D. muscipula and their bactericidal properties. To estimate the antibacterial potential of transformed tissues, MIC and MBC were examined with four antibiotic-resistant, human-pathogenic bacteria. Extracts from clones $\mathrm{P}, \mathrm{L}$, and $\mathrm{E}$ had decreased MIC values for all tested pathogens. Similar to $\mathrm{MBC}$, in the case of $P$. aeruginosa, only clones $\mathrm{L}$ and $\mathrm{E}$ were characterized by increased bactericidal properties. Antibacterial activity of clones $\mathrm{P}, \mathrm{L}$, and $\mathrm{E}$ against S. aureus, E. faecalis, and E. coli increased $33 \%$ compared to NT plants. Extracts from clones $\mathrm{L}$ and $\mathrm{E}$ had decreased MBC value against $P$. aeruginosa (7\%) (Table 3).

\section{Discussion}

To the best of our knowledge, five articles about genetic transformation of carnivorous plants are available (Hirsikorpi et al. 2002; Królicka et al. 2010; Blehova et al. 2015; Miguel et al. 2019; Oropeza-Aburto et al. 2020), while only one is about transformation with wild strains of $R$. rhizogenes bacteria (Królicka et al. 2010). Hirsikorpi et al. (2002) and OropezaAburto et al. (2020) used Rhizobium tumefaciens (former: Agrobacterium tumefaciens) as a vector organism, while in the work of Blehova et al. (2015), R. rhizogenes with green fluorescent protein gene served for Drosera rotundifolia L. transformation. Furthermore, Miguel et al. (2019) explored virus-based plant transformation to create transgenic sundew and pitcher plants, for the overproduction of recombinant proteins. In this study, for the first time, the successful transformation of $D$. muscipula is presented.

It was shown by Franklin et al. (2008) on the Hypericum perforatum $\mathrm{L}$. model that the most limiting factor in successful genetic transformation of plants using Rhizobium bacteria is plant's recalcitrance. When plant cells are challenged with Rhizobium, the stress-induced defense response appears, based on induction of stress-involved gene expression patterns and up-regulation of enzymatic protein activity in the phenylpropanoid pathway, leading to increased synthesis of secondary metabolites (Franklin et al. 2009; Tusevski et al. 2019). Being a rich source of phenolic compounds with strong bactericidal properties, carnivorous plants from the family Droseraceae are hard to transform (Blehova et al. 2015), while transformation of such organisms gives the possibility to

Table 1 Accumulation of phenolic derivatives in non-transformed and transformed tissue of Dionaea muscipula clones. Different letters indicate significant differences between means at $p<0.05$, SD - standard deviation

\begin{tabular}{|c|c|c|c|c|c|c|}
\hline Phenolic derivatives & & NT plants & Clone P & Clone K & Clone L & Clone E \\
\hline Plumbagine & $\mathrm{mg} \times \mathrm{g}^{-1} \mathrm{DW}$ & $69.57^{\mathrm{A}} \pm 4.15$ & $92.40^{\mathrm{B}} \pm 4.41$ & $74.78^{\mathrm{A}} \pm 8.85$ & $101.35^{\mathrm{BC}} \pm 1.79$ & $106.63^{C} \pm 3.47$ \\
\hline Hyperoside & & $4.47^{\mathrm{B}} \pm 0.68$ & $2.06^{\mathrm{A}} \pm 0.28$ & $2.52^{\mathrm{A}} \pm 0.15$ & $2.04^{\mathrm{A}} \pm 0.36$ & $2.33^{\mathrm{A}} \pm 0.45$ \\
\hline Myricetin & & $3.17^{\mathrm{A}} \pm 0.25$ & $3.48^{\mathrm{A}} \pm 0.05$ & $3.37^{\mathrm{A}} \pm 0.26$ & $3.21^{\mathrm{A}} \pm 0.20$ & $3.67^{\mathrm{A}} \pm 0.13$ \\
\hline Quercetin & & $2.21^{\mathrm{AB}} \pm 0.13$ & $2.48^{\mathrm{B}} \pm 0.02$ & $1.64^{\mathrm{A}} \pm 0.48$ & $2.22^{\mathrm{AB}} \pm 0.13$ & $2.59^{\mathrm{B}} \pm 0.08$ \\
\hline Caffeic acid & & $1.16^{\mathrm{A}} \pm 0.05$ & $1.47^{\mathrm{AB}} \pm 0.15$ & $1.34^{\mathrm{AB}} \pm 0.15$ & $1.96^{\mathrm{C}} \pm 0.24$ & $1.65^{\mathrm{BC}} \pm 0.11$ \\
\hline Salicylic acid & & $340.83^{\mathrm{B}} \pm 22.24$ & $600.66^{\mathrm{D}} \pm 12.02$ & $281.04^{\mathrm{A}} \pm 15.02$ & $540.47^{\mathrm{C}} \pm 27.10$ & $649.93^{\mathrm{D}} \pm 25.67$ \\
\hline Ellagic acid & & $8.99^{\mathrm{A}} \pm 0.39$ & $14.43^{\mathrm{B}} \pm 0.21$ & $9.17^{\mathrm{A}} \pm 0.86$ & $15.06^{\mathrm{B}} \pm 1.42$ & $16.51^{\mathrm{B}} \pm 0.64$ \\
\hline
\end{tabular}


Table 2 The productivity of phenolic derivatives in non-transformed and transformed tissue of Dionaea muscipula clones. Different letters indicate significant differences between means at $p<0.05, S D$ standard deviation

\begin{tabular}{|c|c|c|c|c|c|c|}
\hline Phenolic compounds & & NT plants & Clone $\mathrm{P}$ & Clone K & Clone L & Clone E \\
\hline Plumbagine & $\mathrm{mg} \times 8$ weeks $^{-1} \times$ flask $^{-1} \pm \mathrm{SD}$ & $142.5^{\mathrm{A}} \pm 8.51$ & $194.0^{\mathrm{B}} \pm 9.27$ & $118.9^{\mathrm{A}} \pm 14.08$ & $248.0^{\mathrm{C}} \pm 4.37$ & $216.9^{\mathrm{B}} \pm 3.16$ \\
\hline Hyperoside & & $9.2^{\mathrm{B}} \pm 1.40$ & $4.3^{\mathrm{A}} \pm 0.58$ & $4.0^{\mathrm{A}} \pm 0.24$ & $5.0^{\mathrm{A}} \pm 0.88$ & $4.7^{\mathrm{A}} \pm 0.92$ \\
\hline Myricetin & & $6.5^{\mathrm{B}} \pm 0.50$ & $7.3^{\mathrm{BC}} \pm 0.11$ & $5.4^{\mathrm{A}} \pm 0.41$ & $7.9^{C} \pm 0.49$ & $7.5^{\mathrm{BC}} \pm 0.26$ \\
\hline Quercetin & & $4.5^{\mathrm{B}} \pm 0.27$ & $5.2^{\mathrm{B}} \pm 0.04$ & $2.6^{\mathrm{A}} \pm 0.76$ & $5.4^{\mathrm{B}} \pm 0.32$ & $5.3^{\mathrm{B}} \pm 0.17$ \\
\hline Caffeic acid & & $2.4^{\mathrm{AB}} \pm 0.10$ & $3.1^{\mathrm{BC}} \pm 0.32$ & $2.1^{\mathrm{A}} \pm 0.24$ & $4.8^{\mathrm{D}} \pm 0.58$ & $3.4^{\mathrm{C}} \pm 0.23$ \\
\hline Salicylic acid & & $697.9^{\mathrm{B}} \pm 45.55$ & $1261.2^{\mathrm{C}} \pm 25.24$ & $447.1^{\mathrm{A}} \pm 23.90$ & $1322.3^{\mathrm{C}} \pm 52.22$ & $1322.3^{C} \pm 52.22$ \\
\hline Ellagic acid & & $18.4^{\mathrm{A}} \pm 0.80$ & $30.3^{\mathrm{B}} \pm 0.45$ & $14.6^{\mathrm{A}} \pm 1.36$ & $36.9^{\mathrm{C}} \pm 3.48$ & $33.6^{\mathrm{BC}} \pm 1.31$ \\
\hline
\end{tabular}

study pathways involved in the synthesis of valuable secondary metabolites and/or overproducing phytochemicals of interest (Gandhi et al. 2015). Moreover, effective transformation protocols for the Venus flytrap seem to be important tools in the field of physiological, ecological, and evolutionary research (Blehova et al. 2015).

During Rhizobium-mediated transformation, there are a few factors that affect the effectiveness of gene transfer from bacteria to the plant genome. One of them is the explant type (Alok et al. 2016; Hou et al. 2016). In our study, we chose rhizomes of the Venus flytrap as explants for transformation due to a lower concentration of secondary metabolites than that in leaves. The other crucial factor is the selection of the Rhizobium strain. Królicka et al. (2010) showed that during the transformation of Drosera capensis var. alba, R. rhizogenes ATCC 15834 strain was effective, while LBA 9402 and A4 were not conducive to transformation. Secondary metabolites contained in the leaves of medicinal plants can inhibit the growth of bacteria and decrease transformation efficiency (Królicka et al. 2010; Blehova et al. 2015). Additionally, Thiruvengadam et al. (2014a) observed differences in various $R$. rhizogenes strain effectiveness in the establishment of hairy root cultures of Momordica charantia. Wang et al. (2006) showed that induction of hairy roots in Echinacea purpurea was possible with $R$. rhizogenes A4, R1601, and R1000 strains but the performance of each strain was dependent on the type of plant explant. In contrast, the transformation rate of Origanum vulgare was similar for strains 15,834 and K599, while the type of medium affected hairy root appearance (Habibi et al. 2016). In our study, successful transformation of D. muscipula was possible with $R$. rhizogenes LBA 9402 and ATCC 15834, while the A4 strain did not caused T-DNA incorporation into plant genomic DNA. This can be the evidence that LBA 9402 and ATCC 15834 strains are less sensitive to secondary metabolites accumulated in Venus flytrap tissue, which are synthesized as defense compounds.

The presented results demonstrate that independent of the bacterial strain, obtained transformed clones of $D$. muscipula are characterized by the presence of only the rolB gene in plant DNA. Moreover, it was found that each clone (P, K, L, and E) had a single copy of the rolB gene combined in the plant genome. This result is in agreement with the findings of Królicka et al. (2010), where teratomas of transformed sundew had a single copy of the rolB gene. Similarly, in the research of Gangopadhyay et al. (2011), after the transformation of the medicinal plant Plumbago indica, obtained hairy root clones were characterized by a single copy of the rolB gene, which was confirmed with Southern hybridization. The type and copy number of rol genes (A, B, C, or D) transferred from bacteria to the plant genome during T-DNA delivery and combining, takes place accidentally, despite having a direct impact on transformed organism morphology and physiology (Ghimire et al. 2019; Ansari et al. 2019). Transforming a plant with $R$. rhizogenes usually results in hairy root culture creation but sometimes transformed cells can directly regenerate into whole plants (Blehova et al. 2015). Rol genes (the root loci) are
Table 3 Minimal inhibition concentration (MIC) and minimal bactericidal concentration (MBC) of $S$. aureus, E. faecalis, E. coli, and $P$. aeruginosa after treatment with extracts from nontransformed and transformed tissue of Dionaea muscipula clones

\begin{tabular}{|c|c|c|c|c|c|c|c|c|}
\hline & \multirow{2}{*}{\multicolumn{2}{|c|}{$\begin{array}{l}\text { Staphylococcus aureus } \\
\frac{\text { ATCC } 25923}{\mu \mathrm{g} \mathrm{DW} \times \mathrm{mL}^{-1}}\end{array}$}} & \multicolumn{2}{|c|}{$\begin{array}{l}\text { Enterococcus faecalis } \\
\text { ATCC } 19433\end{array}$} & \multirow{3}{*}{$\begin{array}{l}\text { Escherichia coli } \\
\text { ATCC } 25922 \\
\text { MIC }\end{array}$} & \multicolumn{3}{|c|}{$\begin{array}{l}\text { Pseudomonas aeruginosa } \\
\text { ATCC } 27853\end{array}$} \\
\hline & & & & & & & & \\
\hline & MIC & $\mathrm{MBC}$ & MIC & $\mathrm{MBC}$ & & $\mathrm{MBC}$ & MIC & $\mathrm{MBC}$ \\
\hline NT plants & 167 & 500 & 667 & 1250 & 500 & 1250 & 1250 & 1250 \\
\hline Clone P & 83 & 333 & 500 & 833 & 417 & 833 & 1000 & 1250 \\
\hline Clone K & 167 & 500 & 833 & 1250 & 500 & 1250 & 1250 & 1250 \\
\hline Clone L & 83 & 333 & 500 & 833 & 417 & 833 & 1000 & 1166 \\
\hline Clone E & 83 & 333 & 500 & 833 & 417 & 833 & 1000 & 1166 \\
\hline
\end{tabular}


essential for hairy root creation, while the phenotype of transformed plants depends on the number of rol genes incorporated in plant DNA and their expression pattern (Vinterhalter et al. 2015). High expression of the rol gene family particularly stimulates hairy root creation and elongation (Tusevski et al. 2019). The transformation of $D$. muscipula did not affect hairy root formation. These findings can result from the incorporation of only a single copy of the rolB gene in each clone $(\mathrm{P}, \mathrm{K}, \mathrm{L}$, and E) and can be evidence for low expression patterns of the rolB gene in D. muscipula. Conversely, the rolB gene can be a suppressor of cell division and growth (Bulgakov 2008). Królicka et al. (2010) and Blehova et al. (2015) also observed direct organogenesis into whole plants (creation of teratomas) after the transformation of plants from the family Droseraceae with $R$. rhizogenes. Habibi et al. (2016) showed that the hairy root culture of the medicinal plant $O$. vulgare could regenerate into whole plants with a callus phase intervening between them. Transformed cells differentiated into whole plants can conduct changes in leaf and shoot morphology, which is called "hairy root syndrome". Clone L was obtained after D. muscipula transformation and characterized by longer leaves and bigger leaf-traps than NT plants and other transformed clones, which could be the consequence of transformation.

Plant transformation with wild strains of the $R$. rhizogenes bacteria is a valuable biotechnology tool, allowing the creation of fast-growing, genetically stable organisms, with a high content of secondary metabolites (Gandhi et al. 2015). Since fast biomass accumulation in plant tissue cultures is one of the most important features in the industry field, research has been conducted to determine the growth parameters of hairy root cultures obtained after $R$. rhizogenes inoculation (Georgiev et al. 2007). Tusevski et al. (2019) showed great variation in the growth of $H$. perforatum hairy roots, although each clone was obtained using the same bacterial strain. Similar variability of growth parameters was observed by Tusevski et al. (2017). Additionally, hairy root lines of Rehmannia elata showed large differences in fresh weight growth rate and DW accumulation (Piątczak et al. 2019). Polygonum multiflorum Thunb. and $M$. charantia hairy roots reached nearly a 10 -fold increase in the growth of fresh weight after 20 days (Thiruvengadam et al. 2014a, b). Binoy et al. (2016) reported a 12-fold increase in Plumbago rosea hairy roots. Nevertheless, little is known about the growth of teratomas. Królicka et al. (2010) demonstrated that teratomas of $D$. capensis had a three times higher growth index than nontransformed plants. In this study, for the first time, growth parameters of transformed $D$. muscipula plants were evaluated. The obtained results showed that clone $\mathrm{L}$ had increased GI in comparison to NT plants, while clone K accumulated significantly less biomass than control plants, with simultaneously increased DW content. In our study, D. muscipula transformed clones' growth characteristics had no connection with the bacteria strain. Differences between the obtained clones using the same bacteria strain (LBA 9402 or ATCC 15834) may have resulted from the fact that each clone originated from different transformation events. Heterogeneity among transgenic clones could depend on physiological conditions of the transformed organism, expression of $\mathrm{rol}$ genes, and copy numbers of genes from bacterial T-DNA inserted in the plant genome (Tusevski et al. 2019).

Franklin et al. (2009) studied the basis of plant recalcitrance under co-cultivation with Rhizobium bacteria. Inoculation of plant tissue conducted for the up-regulation of gene expression involved in defense response consequently led to increased secondary metabolism and affected accumulation of phytochemicals (Hou et al. 2016). In contrast, little is known about the metabolism of secondary compounds after the incorporation of bacterial T-DNA in the plant genome. Tusevski et al. (2019) reported that hairy root culture had the same, or an even greater, ability to produce valuable metabolites. It is postulated that the rol genes family can act as an endogenous elicitor and conduct changes in the phytochemical profile of medicinal plants (Tusevski et al. 2019). From the industrial point of view, modified organisms can be a low cost, environmentally friendly source of valuable chemicals (Gandhi et al. 2015), while the productivity of secondary compounds can be greatly improved (Królicka et al. 2010). Increased production of total phenolic content, total flavonoids, myricetin, quercetin, caffeic acid, and salicylic acid was shown to be a consequence of the upregulation of the rolC gene in hairy roots of Ligularia fischeri (Ansari et al. 2019). Hairy roots of H. perforatum showed greater activity of enzymes involved in the phenylpropanoid pathway and in consequence, accumulated significantly more total phenolic and flavonoid content in comparison to nontransformed roots (Tusevski et al. 2017). Ghimire et al. (2019) reported the increased synthesis of total phenolic and flavonoid content with simultaneously higher production of selected phenolic derivatives in hairy root cultures of Aster scaber and postulated the vital role of rol genes in the greater synthesis of these compounds. These results could be based on the phenomenon of turning on the transcription of defense genes by the rol genes family (Thiruvengadam et al. 2014b). Increased synthesis of phenolic compounds in hairy root cultures compared to non-transformed plants were also reported (Thiruvengadam et al. 2014a). Transformation of D. muscipula plants also affected the metabolism of phenolic compounds in obtained teratomas, although only the rolB gene was confirmed to be incorporated in the plant genome. Three of the four selected clones $(\mathrm{P}, \mathrm{L}$, and $\mathrm{E})$ had significantly higher total phenolic, phenylpropanoid, flavonoid, and anthocyanins content, than NT plants. It may be connected with the fact that the rolB gene was proved as the strongest inducer of secondary metabolites in the rol gene family (Bulgakov 2008).

Additionally, analysis of the use of HPLC showed great variation in phenolic derivatives accumulation in transformed tissues of the Venus Flytrap. The highest plumbagin 
accumulation was observed in clone $\mathrm{E}$ after a 1.5 -fold increase of this metabolite. Conversely, clone $\mathrm{L}$ was characterized by the greatest plumbagin productivity (1.7-fold increase compared to NT plants). Our observations agree with the results of Królicka et al. (2010), where teratomas of D. capensis had significantly increased accumulation and productivity of ramentaceone (1,4-naphtoquinone derivative) in comparison to non-transformed plants. Moreover, teratomas of D. muscipula accumulated over 20 times more plumbagin $\left(106.63 \mathrm{mg} \times \mathrm{g}^{-1} \mathrm{DW}\right)$ than hairy roots of $P$. indica $(4.9 \mathrm{mg} \times$ $\mathrm{g}^{-1} \mathrm{DW}$ ), as reported by Gangopadhyay et al. (2011). Furthermore, both accumulation and productivity of phenolic acids, like caffeic, salicylic, and ellagic acid, were increased as a consequence of transformation in some clones of D. muscipula created during the transformation process mediated by $R$. rhizogenes bacteria. These findings agree with previous findings (Ghimire et al. 2019; Ansari et al. 2019), where the production of phenolic acids in hairy roots of transformed plants was significantly increased in comparison to NT plants. In contrast to the results of Ansari et al. (2019), in clones of D. muscipula, metabolism of myricetin and quercetin was not affected by transformation, while the level of hyperoside in transformed plant tissue was decreased. In contrast to clones $\mathrm{P}, \mathrm{L}$, and $\mathrm{E}$, synthesis of phenolic compounds in clone $\mathrm{K}$ was the same or decreased, compared to NT plants. Similar observations were reported by Wang et al. (2006) in the culture of hairy roots of E. purpurea. The expression pattern of rol genes in clone $\mathrm{K}$ is likely lower than in other obtained clones (Tusevski et al. 2017).

At the same time, medicinal plant tissue culture gives the possibility for producing valuable secondary metabolites and to quickly screen the biological properties of elite plant genotypes. Due to this, research on the healing properties of plantderived extracts is available (Niazian 2019). Many studies were conducted to estimate the antimicrobial potential of medicinal plants because of the growing resistance of human pathogenic bacteria to available antibiotics (Krychowiak et al. 2014). In this article, we present for the first time, the bactericidal properties of transformed $D$. muscipula plants against Gram-positive and Gram-negative bacteria strains. It was reported by Krolicka et al. (2008) and Makowski et al. (2020) that extracts from carnivorous plants from the family Droseraceae are highly biologically active thanks to a high content of phenolic compounds, especially 1,4-naphtoquinone derivatives. According to this, biotechnological studies conducted for the improvement of healing properties in carnivorous plants seem to be needed. Ansari et al. (2019) showed that hairy roots of $L$. fischeri had greater antimicrobial activity than non-transformed tissue, against various clinical bacteria strains. Moreover, the bactericidal properties of hairy roots were improved for both Gram-positive and Gram-negative bacteria. More pronounced activity against pathogenic bacteria was also observed in hairy roots of $M$. charantia
(Thiruvengadam et al. 2014a), P. multiflorum (Thiruvengadam et al. 2014b), and H. perforatum (Tusevski et al. 2017). This phenomenon is directly connected with the higher production of biologically active phytochemicals in this type of transformed tissue. In the presented study, we evaluated the antimicrobial potential of extracts derived from transformed clones of the Venus flytrap against two Grampositive ( $S$. aureus and E. faecalis) and two Gram-negative (E. coli and P. aeruginosai) bacteria. Clones $\mathrm{P}, \mathrm{L}$, and $\mathrm{E}$ showed improved bactericidal properties against $S$. aureus, $E$. faecalis, and E. coli, while only extracts from clones L and $\mathrm{E}$ had strong activity against $P$. aeruginosa. It may be connected to the increased level of salicylic acid in these clones. Our results agree with data presented by Wen et al. (2019), where $P$. aeruginosa was more resistant to Orostachys cartilaginous-derived extracts in comparison to the Grampositive pathogen Bacillus subtilis. Except for plumbagin, which was proven to be biologically active and potent, phenolic acids have a crucial role in the antibacterial activity of medicinal plants. In this study, transformed clones of D. muscipula with increased bactericidal properties accumulated significantly more salicylic and ellagic acid. Gomes et al. (2018) showed that among the tested species, Eucalyptus globules had the highest antimicrobial activity, rich in ellagic acid glycoside. Clone $\mathrm{K}$ did not show improvement in antimicrobial potential, which agrees with results obtained from the estimation of secondary metabolite content. Interestingly, according to the obtained results from MBC tests, the Gram-positive pathogen E. faecalis had the same sensitivity to extracts derived from $D$. muscipula tissue as Gram-negative E. coli. This observation is in opposition to previous findings by Krolicka et al. (2008) and Makowski et al. (2020). Because Gram-positive bacteria do not have a lipopolysaccharide membrane surrounding the cell wall (Ansari et al. 2019) and permeability of antimicrobial compounds is increased (Tusevski et al. 2015), extracts from medicinal plants have stronger bactericidal properties against such pathogens. Nevertheless, the obtained results indicate that D. muscipula transformed clones had great bactericidal activity and can be used as a source of biologically active compounds in the pharmacological field.

Author contributions W.M., A.K., and K.M.T. designed the experiment, interpreted, and discussed the data. W.M. performed the statistical analysis, prepared the graphical part of the manuscript, and wrote the manuscript. W.M., A.K., and B.T. contributed to data acquisition and R.B. developed the analytical method for the determination of phenolic compounds using HPLC. A.K., K.M.T., B.T., A.N., J.Z., and A.P. checked and corrected the manuscript. W.M., AN, and JZ performed Southern hybridizations. A.P. consulted PCR and Southern hybridization experiments. All authors proofread the manuscript, agreed on its contents, and consented to its submission.

Funding This study was funded by the National Science Centre, Poland (grant number 2018/31/N/NZ9/00581). 
Data availability The datasets generated during and/or analyzed during the current study are available from the corresponding author on reasonable request.

\section{Compliance with ethical standards}

Conflict of interests The authors declare that they have no conflict of interests.

Ethical approval This article does not contain any studies with human participants or animals performed by any of the authors.

Open Access This article is licensed under a Creative Commons Attribution 4.0 International License, which permits use, sharing, adaptation, distribution and reproduction in any medium or format, as long as you give appropriate credit to the original author(s) and the source, provide a link to the Creative Commons licence, and indicate if changes were made. The images or other third party material in this article are included in the article's Creative Commons licence, unless indicated otherwise in a credit line to the material. If material is not included in the article's Creative Commons licence and your intended use is not permitted by statutory regulation or exceeds the permitted use, you will need to obtain permission directly from the copyright holder. To view a copy of this licence, visit http://creativecommons.org/licenses/by/4.0/.

\section{References}

Alok A, Vishnu S, Pala Z, Kumar J, Kudale S, Desai N (2016) In vitro regeneration and optimization of factors affecting Agrobacterium mediated transformation in Artemisia Pallens, an important medicinal plant. Physiol Mol Biol Plants 22(2):261-269. https://doi.org/ 10.1007/s12298-016-0353-3

Ansari MA, Chung IM, Rajakumar G, Alzohairy MA, Almatroudi A, Khanna VG, Thiruvengadam M (2019) Evaluation of polyphenolic compounds and pharmacological activities in hairy root cultures of Ligularia fischeri Turcz. f. spiciformis (Nakai). Molecules 24:1586. https://doi.org/10.3390/molecules24081586

Banasiuk R, Kawiak A, Krolicka A (2012) In vitro cultures of carnivorous plants from the Drosera and Dionaea genus for the production of biologically active secondary metabolites. Biotechnologia 93:8796. https://doi.org/10.5114/bta.2012.46572

Bekesiova I, Nap JP, Mlynarova L (1999) Isolation of high quality DNA and RNA from leaves of the carnivorous plant Drosera rotundifolia. Plant Mol Biol Report 17:269-277. https://doi.org/10.1023/A: 1007627509824

Binoy J, Silja PK, Dhanya BP, Satheeshkumar K (2016) In vitro cultivation of hairy roots of Plumbago rosea L. in a customized reaction kettle for the production of plumbagin-an anticancer compound. Ind Crop Prod 87:89-95. https://doi.org/10.1016/j.indcrop.2016.04.023

Blehova A, Svubova R, Lukacova Z, Moravcikova J, Matusikova I (2015) Transformation of sundew: pitfalls and promises. Plant Cell Tissue Organ Cult 120:681-687. https://doi.org/10.1007/s11240-014-0635-9

Boonsnongcheepa P, Sae-fooa W, Banpakoata K, Channaronga S, Chitsaithana S, Uafuaa P, Puthaa W, Kerdsiria K, Putaluna W (2019) Artificial color light sources and precursor feeding enhance plumbagin production of the carnivorous plants Drosera burmannii and Drosera indica. J Photochem Photobiol B Biol 199:111628. https://doi.org/10.1016/j.jphotobiol.2019.111628

Bulgakov VP (2008) Functions of rol genes in plant secondary metabolism. Biotechnol Adv 26:318-324. https://doi.org/10.1016/j. biotechadv.2008.03.001
Canter PH, Thomas H, Ernst E (2005) Bringing medicinal plants into cultivation: opportunities and challenges for biotechnology. Trends Biotechnol 23(4):180-185. https://doi.org/10.1016/j.tibtech.2005. 02.002

Franklin G, Conceição LFR, Kombrink E, Dias ACP (2008) Hypericum perforatum plant cells reduce Agrobacterium viability during cocultivation. Planta 227:1401-1408. https://doi.org/10.1007/ s00425-008-0691-7

Franklin G, Conceiçăo LFR, Kombrink E, Dias ACP (2009) Xanthone biosynthesis in Hypericum perforatum cells provides antioxidant and antimicrobial protection upon biotic stress. Phytochemistry 70: 60-68. https://doi.org/10.1016/j.phytochem.2008.10.016

Fukumoto LR, Mazza G (2000) Assessing antioxidant and prooxidant activities of phenolic compounds. J Agric Food Chem 48:35973604. https://doi.org/10.1021/jf000220w

Gaascht F, Dicato M, Diederich M (2013) Venus flytrap (Dionaea muscipula Solander ex Ellis) contains powerful compounds that prevent and cure cancer. Front Oncol 3:202. https://doi.org/10. 3389/fonc.2013.00202

Gandhi SG, Mahajan V, Bedi YS (2015) Changing trends in biotechnology of secondary metabolism in medicinal and aromatic plants. Planta 241:303-317. https://doi.org/10.1007/s00425-014-2232-x

Gangopadhyay M, Chakraborty D, Bhattacharyya S, Bhattacharya S (2010) Regeneration of transformed plants from hairy roots of Plumbago indica. Plant Cell Tissue Organ Cult 102:109-114. https://doi.org/10.1007/s11240-010-9702-Z

Gangopadhyay M, Dewanjee S, Chakraborty D, Bhattacharya S (2011) Role of exogenous phytohormones on growth and plumbagin accumulation in Plumbago indica hairy roots and conservation of elite root clones via synthetic seeds. Ind Crop Prod 33:445-450. https:// doi.org/10.1016/j.indcrop.2010.10.030

Georgiev MI, Pavlov AI, Bley T (2007) Hairy root type plant in vitro systems as sources of bioactive substances. Appl Microbiol Biotechnol 74: 1175-1185. https://doi.org/10.1007/s00253-007-0856-5

Ghimire BK, Thiruvengadam M, Chung IM (2019) Identification of elicitors enhances the polyphenolic compounds and pharmacological potential in hairy root cultures of Aster scaber. S Afr J Bot 125: 92-101. https://doi.org/10.1016/j.sajb.2019.07.006

Gomes F, Martins N, Barros L, Rodrigues ME, Oliveira MBPP, Henriques M, Ferreira ICFR (2018) Plant phenolic extracts as an effective strategy to control Staphylococcus aureus, the dairy industry pathogen. Ind Crop Prod 112:515-520. https://doi.org/10.1016/j. indcrop.2017.12.027

Guillon S, Tremouillaux-Guiller J, Pati PK, Rideau M, Gantet P (2006) Hairy root research: recent scenario and exciting prospects. Curr Opin Plant Biol 9:341-346. https://doi.org/10.1016/j.pbi.2006.03.008

Habibi P, Grossi de Sa MF, Lopes da Silva AL, Makhzoum A, da Luz Costa J, Borghetti IA, Soccol CR (2016) Efficient genetic transformation and regeneration system from hairy root of Origanum vulgare. Physiol Mol Biol Plants 22(2):271-277. https://doi.org/ 10.1007/s12298-016-0354-2

Hirsikorpi M, Kamarainen T, Teeri T, Hohtola A (2002) Agrobacteriummediated transformation of round leaved sundew (Drosera rotundifolia L.). Plant Sci 162:537-542. https://doi.org/10.1016/ S0168-9452(01)00592-1

Hou W, Shakya P, Franklin G (2016) A perspective on Hypericum perforatum genetic transformation. Front Plant Sci 7:879. https:// doi.org/10.3389/fpls.2016.00879

Kawiak A, Domachowska A, Królicka A, Smolarska M, Łojkowska E (2019) 3-Chloroplumbagin induces cell death in breast cancer cells through MAPK-mediated Mcl-1 inhibition. Front Pharmacol 10: 784. https://doi.org/10.3389/fphar.2019.00784

Królicka A, Staniszewska I, Bielawski K, Maliński E, Szafranek J, Łojkowska E (2001) Establishment of hairy root cultures of Ammi majus. Plant Sci 160:259-264. https://doi.org/10.1016/S01689452(00)00381-2 
Krolicka A, Szpitter A, Gilgenast E, Romanik G, Kaminski M, Lojkowska E (2008) Stimulation of antibacterial naphthoquinones and flavonoids accumulation in carnivorous plants by addition of elicitors. Enzym Microb Technol 42:216-221. https://doi.org/10. 1016/j.enzmictec.2007.09.011

Królicka A, Szpitter A, Maciąg A, Biskup E, Gilgenast E, Romanik G, Kamiński M, Wegrzyn G, Łojkowska E (2009) Antibacterial and antioxidant activity of the secondary metabolites from in vitro cultures of the Alice sundew (Drosera aliciae). Biotechnol Appl Biochem 53:175-184. https://doi.org/10.1042/BA20080088

Królicka A, Szpitter A, Stawujak K, Barański R, Gwizdek-Wiśniewska A, Skrzypczak A, Kamiński M, Łojkowska E (2010) Teratomas of Drosera capensis var. alba as a source of naphthoquinone: Ramentaceone. Plant Cell Tissue Organ Cult 103:285-292. https:// doi.org/10.1007/s11240-010-9778-5

Krychowiak M, Grinholc M, Banasiuk R, Krauze-Baranowska M, Głód D, Kawiak A, Królicka A (2014) Combination of silver nanoparticles and Drosera binata extract as a possible alternative for antibiotic treatment of burn wound infections caused by resistant Staphylococcus aureus. PLoS One 9:e115727. https://doi.org/10. 1371/journal.pone.0115727

Libik-Konieczny M, Michalec-Warzecha Ż, Dziurka M, Zastawny O, Konieczny R, Rozpadek P, Pistelli L (2020) Steviol glycosides profile in Stevia rebaudiana Bertoni hairy roots cultured under oxidative stress-inducing conditions. Appl Microbiol Biotechnol 104: 5929-5941. https://doi.org/10.1007/s00253-020-10661-5

Makowski W, Tokarz B, Banasiuk R, Królicka A, Dziurka M, Wojciechowska R, Tokarz KM (2019) Is a blue-red light a good elicitor of phenolic compounds in the family Droseraceae? A comparative study. J Photochem Photobiol B Biol 201:111679. https:// doi.org/10.1016/j.jphotobiol.2019.111679

Makowski W, Tokarz KM, Tokarz B, Banasiuk R, Witek K, Królicka A (2020) Elicitation-based method for increasing the production of antioxidant and bactericidal phenolic compounds in Dionaea muscipula J. Ellis tissue. Molecules 25:1794. https://doi.org/10. 3390/molecules25081794

Maniatis T, Fritsch EF, Sambrook J (1982) Molecular cloning. In: A laboratory manual, vol 9. Cold Spring Harbor Laboratory, Cold Spring Harbor, pp 213-214. https://doi.org/10.1016/01677799(91)90068-S

Miguel S, Nisse E, Biteau F, Rottloff S, Mignard B, Gontier E, Hehn A, Bourgaud F (2019) Assessing carnivorous plants for the production of recombinant proteins. Front Plant Sci 10:793. https://doi.org/10. 3389/fpls.2019.00793

Murashige T, Skoog F (1962) A revised medium for rapid growth and bioassays with tobacco tissue cultures. Physiol Plant 15:473-497. https://doi.org/10.1111/j.1399-3054.1962.tb08052.x

Niazian M (2019) Application of genetics and biotechnology for improving medicinal plants. Planta 249:953-973. https://doi.org/10.1007/ s00425-019-03099-1

Nowicka A, Tokarz B, Zwyrtková J, Dvořák Tomaštíková E, Procházková K, Ercan U, Finke E, Rozhon E, Poppenberger E, Otmar M, Niezgodzki I, Krečmerová M, Schubert I, Pecinka A (2020) Comparative analysis of epigenetic inhibitors reveals different degrees of interference with transcriptional gene silencing and induction of DNA damage. Plant J 102(1):68-84. https://doi.org/10. 1111/tpj.14612

Oropeza-Aburto A, Cervantes-Pérez SA, Albert VA, Herrera-Estrella L (2020) Agrobacterium tumefaciens mediated transformation of the aquatic carnivorous plant Utricularia gibba. Plant Methods 16:50. https://doi.org/10.1186/s13007-020-00592-7

Padhye S, Dandawate P, Yusufi M, Ahmad A, Sarkar FH (2010) Perspectives on medicinal properties of plumbagin and its analogs. Med Res Rev 32:1131-1158. https://doi.org/10.1002/med.20235
Piątczak E, Jeleń A, Makowczyńska J, Zielińska S, Kuźma Ł, Balcerczak E (2019) Establishment of hairy root cultures of Rehmannia elata N.E. Brown ex Prain and production of iridoid and phenylethanoid glycosides. Ind Crop Prod 137:308-314. https://doi.org/10.1016/j. indcrop.2019.05.022

Putalun W, Udomsin O, Yusakul G, Juengwatanatrakul T, Sakamoto S, Tanaka H (2010) Enhanced plumbagin production from in vitro cultures of Drosera burmanii using elicitation. Biotechnol Lett 32: 721-724. https://doi.org/10.1007/s10529-010-0202-3

Swain T, Hillis WE (1959) Phenolic constituents of Prunus domestica. I quantitative analysis of phenolic constituents. J Sci Food Agric 10: 63-68. https://doi.org/10.1002/jsfa.2740100110

Thiruvengadam M, Praveen N, John KMM, Yang Y, Kim S, Chung I (2014a) Establishment of Momordica charantia hairy root cultures for the production of phenolic compounds and determination of their biological activities. Plant Cell Tissue Organ Cult 118:545-557. https://doi.org/10.1007/s11240-014-0506-4

Thiruvengadam M, Praveen N, Kim E-H, Kim S-H, Chung I-M (2014b) Production of anthraquinones, phenolic compounds and biological activities from hairy root cultures of Polygonum multiflorum Thunb. Protoplasma 251:555-566. https://doi.org/10.1007/s00709-013-0554-3

Tokarz K, Makowski W, Banasiuk R, Królicka A, Piwowarczyk B (2018) Response of Dionaea muscipula J. Ellis to light stress in in vitro: physiological study. Plant Cell Tissue Organ Cult 134(1): 65-77. https://doi.org/10.1007/s11240-018-1400-2

Tokarz KM, Makowski W, Tokarz B, Hanula M, Sitek E, Muszyńska E, Jędrzejczyk R, Banasiuk R, Chajec Ł, Mazur S (2020) Can Ceylon leadwort (Plumbago zeylanica L.) acclimate to lead toxicity? - studies of photosynthetic apparatus effciency. Int J Mol Sci 21:1866. https://doi.org/10.3390/ijms21051866

Tusevski O, Petreska Stanoeva J, Stefova M, Gadzovska Simic S (2015) Agrobacterium enhances xanthone production in Hypericum perforatum cell suspension. Plant Growth Regul 76:199-210. https://doi.org/10.1007/s10725-014-9989-6

Tusevski O, Vinterhalter B, Krstić Milošević D, Soković M, Ćirić A, Vinterhalter D, Zdravković Korać S, Petreska Stanoeva J, Stefova M, Gadzovska Simic S (2017) Production of phenolic compounds, antioxidant and antimicrobial activities in hairy root and shoot cultures of Hypericum perforatum L. Plant Cell Tissue Organ Cult 128: 589-605. https://doi.org/10.1007/s11240-016-1136-9

Tusevski O, Petreska Stanoeva J, Stefova M, Spasenoski M, Gadzovska Simic S (2019) State of antioxidant systems and phenolic compounds' production in Hypericum perforatum L. hairy roots. Acta Physiol Plant 41:132. https://doi.org/10.1007/s11738-019-2919-5

Vinterhalter B, Zdravkovic-Korac S, Mitic N, Bohanec B, Vinterhalter D, Savic J (2015) Effect of sucrose on shoot regeneration in Agrobacterium transformed Hypericum perforatum L. roots. Acta Physiol Plant 37:37. https://doi.org/10.1007/s11738-015-1785-z

Wang B, Zhang G, Zhu L, Chen L, Zhang Y (2006) Genetic transformation of Echinacea purpurea with Agrobacterium rhizogenes and bioactive ingredient analysis in transformed cultures. Colloids Surf B Biointerfaces 53:101-104. https://doi.org/10.1016/j.colsurfb. 2006.08.003

Wen T, Hao YJ, An XL, Sun HD, Li YR, Chen X, Piao XC, Lian ML (2019) Improvement of bioactive compound accumulation in cell cultures of Orostachys cartilaginous A. Bor. through elicitation with salicylic acid and effect of cell extract on bioactive activity. Ind Crop Prod 139:111570. https://doi.org/10.1016/j.indcrop.2019.111570

Publisher's note Springer Nature remains neutral with regard to jurisdictional claims in published maps and institutional affiliations. 